\title{
Evaluation of Selected Effects of Pavement Riding Quality on Logistics Costs in South Africa
}

\author{
AUTHORS: \\ Wynand J. vdM. Steyn (Corresponding author) ${ }^{1}$, Wilna Bean ${ }^{2}$, David King ${ }^{2}$, Julius Komba ${ }^{2}$ \\ ${ }^{1}$ University of Pretoria \\ Lynnwood road \\ Hatfield \\ Pretoria \\ South Africa \\ 0002 \\ Tel: +27124202171 \\ wynand.steyn@up.ac.za \\ ${ }^{2}$ CSIR Built Environment \\ PO Box 395 \\ Pretoria \\ South Africa \\ 0001 \\ wbean@,csir.co.za \\ dking@csir.co.za \\ jkomba@csir.co.za
}

\begin{abstract}
The efficient operation of a country's economy depends, inter alia, on an efficient logistical system to ensure that goods can be transported efficiently between producers and users. The costs of logistics include aspects such as the transport, storage, inventory and management costs. Of these, the transport costs are directly influenced by the condition of the transport infrastructure. In this paper the effects of specifically road riding quality on the costs of logistics is evaluated. This is done through analysis of data obtained from a Logistics Service Provider on actual truck costs (specifically vehicle damage and maintenance) as well as road riding quality data for the routes used by the company. Analysis of the data indicated that the vehicle operating costs increased with decreasing riding quality (as would be expected). The benefit of spending adequate resources on maintenance of routes in a country to decrease the vehicle operations costs of vehicle fleets and ultimately the logistical costs of the country has been verified. It is recommended that the study be broadened to incorporate a larger sample of vehicles and road conditions.
\end{abstract}

\section{INTRODUCTION}

The efficient operation of a country's economy is dependent on a number of factors. These may include an efficient transport system, efficient logistics system and efficient economical system. One factor that became more visible in recent times is the cost of the logistics (goods transportation) in a country. These costs have a direct effect on the broader economy, as logistics cost is usually absorbed through increasing end-product cost to the consumer. The higher end-product cost may lead to a decrease in the global competitiveness of a country, since products are more expensive in the global market. Various studies have been performed over the years regarding the components of the cost of logistics and the following factors are typically incorporated into such costs:

- Transport costs;

- $\quad$ Storage and port costs;

- Inventory carrying costs, and

- Management, admin and profit (1).

The control and efficient management of these costs are important to ensure that the costs of logistics in a country do not become out of balance with the cost of general goods. The costs of logistics in a country typically range between 10 per cent and 20 per cent (2).

Road roughness is used as a primary indication of the condition of a road by engineers. This is mainly due to the fact that most structural and functional pavement defects (cracking, rutting, potholes, unevenness etc.) 
translate to an increase in road roughness (and a decrease in riding quality). The development of these defects over time on a road typically leads to the increase in road roughness over the life of a road. Maintenance of roads (through resurfacing and rehabilitation) is used to reinstate the riding quality to acceptable levels.

Road roughness affects the Vehicle Operating Costs (VOCs) directly as the uneven surface of the road is transposed to the body of the vehicle through the tires and suspension systems and this typically leads to damage of vehicle components and also increase in the energy required to move the vehicle (leading to increased fuel costs). A portion of this may be offset by lower operational speeds on uneven roads. Further, depending on the type of suspension and the general vehicular dimension, these vibrations generated by the uneven road surface may lead to damage to the cargo being transported (3). Various studies have been conducted to investigate the effects of road roughness on VOCs (e.g. 4, 5, 6). One of the typical outcomes of these studies is equations to relate road conditions to the components of VOCs. These relationships can be used to set optimum strategies for maintaining pavements at adequate levels of service.

In South Africa (SA) an annual State of Logistics (SOL) survey has been conducted since 2004.

Recently, an attempt was made to broaden the SOL surveys to also evaluate the potential effect of riding quality on the broader state of the logistics, as it was realized that inadequate road conditions would have a direct effect on the operational costs of vehicle, and therefore on the cost of logistics in the country. In this study actual Vehicle Operating Cost (VOC) data obtained from Imperial Logistics (the leading Logistics Service Provider (LSP) in southern Africa) were used to analyze the effects of the actual riding quality of the roads used by these vehicles on the VOCs. Existing VOC models were evaluated and the benefit cost ratios of improving roads with inadequate riding qualities evaluated.

The methodology includes identification of costs that can typically be attributed to deteriorating riding quality and analysis of the potential effects that worsening road conditions can have on each of the identified costs (based on actual data from Imperial Logistics). The outcome of this analysis forms an important part of the annual SOL survey for South Africa.

This paper details the project in the SOL where the potential effects of inadequate riding quality on the logistics costs in SA were evaluated. First, background is provided on the cost of logistics, the vehicle components affected by riding quality changes and the background to the annual SOL surveys and the specific study. The data used for the analyses are then presented and discussed and finally, the beneficial effects of improving existing road riding quality against the cost of operating trucks on roads with inadequate riding quality is evaluated. The main purpose of the broader study on which the paper is based is to investigate the effect of road roughness on repair and maintenance costs of trucks on typical South African roads.

\section{DETAILS ON SPECIFIC CONCEPTS}

\section{Concept of vehicle-pavement interaction}

Vehicle-Pavement Interaction (V-PI) can be defined as the system in which the vehicle and pavement exert forces on each other (7). It is affected by both pavement surface condition and vehicle characteristics (including properties of the tires, suspension, configurations and speed). Pavement roughness is the primary ride excitation source $(8,9)$.

\section{Postulated linkages between road quality and logistical costs}

There are many ways in which bad road quality can have a direct, or indirect, influence on the logistics cost in a country. Some of the potential effects that worsening road quality can have on logistics cost and the broader economy of a country are illustrated in Figure 1 (3). Uneven road surfaces will result in an increase in vibrations experienced by a vehicle traveling on that particular road which in turn may lead to increased damages to the transported cargo and increased vehicle damages. A potential approach that can be followed to reduce vehicle and cargo damages is to improve the packaging of products or the design of vehicles in order to minimize the effects of bad roads. This is not an economically feasible solution as this will increase packaging and/or vehicle design and manufacturing costs with the sole purpose to protect vehicles and cargo for trips between suppliers and customers.

The additional packaging, vehicle maintenance, design and manufacturing costs associated with deteriorating road quality can eventually be translated into increased logistics cost and an increase in logistics cost can potentially be absorbed by increasing the cost of end products. This will adversely affect the broader economy of a country.

Vibrations caused by uneven road surfaces increase the dynamic load of vehicles on the road, resulting in faster road deterioration rates. Faster road deterioration rates can be translated into an increase in road maintenance and reconstruction costs for the same amount of cargo transported. This will also have a negative impact on the economy of a country. 
Another manner in which deteriorating road quality can adversely impact the economy of a country is through increased fuel consumption. It is known that the fuel consumption of vehicles on uneven roads increase (10). Inadequate riding quality thus leads to more fuel consumed for the same amount of cargo transported. This eventually translates to an increase in carbon emissions and the use of natural resources which will increase environmental costs significantly.

Finally, congestion and overloading of roads will result in faster road deterioration rates, a decrease in the lifespan of roads and therefore an increase in road maintenance and reconstruction costs. This can adversely impact the economy.

\section{Background to the State of Logistics Survey for South Africa}

The State of Logistics (SOL) Survey for South Africa is an annual initiative initiated by the CSIR in 2004 (1). The purpose of these surveys is to evolve a comprehensive picture of the logistics and supply chain sector in South Africa, incorporating a macroeconomic viewpoint (top-down), an industry-level perspective (bottom-up), and a small business development perspective that deals with logistics as a developmental constraint for Small, Medium and Micro Enterprises (SMMEs) in urban and isolated rural environments.

The multiple perspectives considered by the SOL survey include established areas of research such as costs modeling, transport economics and supply chain analysis, as well as areas such as the role of logistics in socio-economic development. The research methodology reflects this holistic approach, as well as the relative maturity of these research areas. A more formal and quantitative approach is adopted for the development of the costs of logistics, based on the American model of calculating logistics cost, and for the land freight transportation cost calculations while a more qualitative and exploratory approach is applied to the industry, small business and economic development perspective.

The $5^{\text {th }}$ Annual SOL survey for South Africa, entitled "Logistics value and cost drivers from a macro and micro economic perspective", was released in April 2009 (11) and the $6^{\text {th }}$ SOL survey, entitled "Logistics value and cost driving macro and micro-economic change towards global competitiveness and sustainability" was released in April 2010 (12). Logistics costs for 2007 in South Africa amounted to R317 billion (approximately $\$ 42.3$ billion (July 2010 exchange rate)) or 15.9 per cent of South Africa's gross domestic product (GDP), a rise of 1 per cent from the previous year. In comparison, the United States of America's logistics costs (for the same period) were 10.1 per cent of GDP. Although the scales of the two economies differ widely, the difference is significant. Transport dominated the logistics cost distribution in South Africa and contributed 53 per cent (11). This is much larger than the world average of 39 per cent. Inventory carrying cost increased significantly and more than doubled between 2004 and 2007, whereas transport grew by more than 50 per cent (Figure 2 (11)).

Land freight transport's impact on domestic logistics costs remains the biggest challenge for South Africa. Close to 1.6 billion ton of freight was moved in South Africa during 2007, of which 1.4 billion ton (87 per cent) was moved by road at an average transport distance of $178 \mathrm{~km}$, delivering 245 billion ton-km (66 per cent). Rail only contributed 205 million ton (13 per cent) at an average transport distance of $629 \mathrm{~km}$, delivering 129 billion ton-km (34 per cent). The skewed reliance on road transport in South Africa, especially on the major long distance corridors, places a heavy burden on road infrastructure maintenance and delivery and increases logistics costs for the country. Attention is currently focused on evaluating the options of moving various commodities to rail, to lower the logistics costs and the effect of truck transport on the country' roads $(11,13)$.

\section{Relationships for VOC}

Costs associated with road transport can be divided into three major groups. These are road construction costs, road maintenance costs and road-user costs. Road-user costs are the biggest proportion of total road transport cost $(14,15,16,17)$. Improvements in road conditions typically reduce vehicle operating costs and ultimately generate benefits to the national economy. The World Bank initiated a series of studies of road user costs (14) in Brazil, Kenya, the Caribbean and India with the objective of determining trade-offs between initial road construction costs, maintenance costs and road user costs (reported as Highway Design and Maintenance Standards Models (HDM-III)) $(14,18)$. These models were refined using road users and environmental effects and also calibrated for specific countries' own transport conditions (19). In SA such calibration efforts lead to a set of local relationships for calculating fuel consumption, tire wear, maintenance costs, interest costs and depreciation costs as related to road condition (16). Although the existing relationships for SA conditions were evaluated and improvements recommended in a recent research study (20), the discussion on these improvements do not form part of this paper. 


\section{PROJECT DESCRIPTION}

The project on which this paper is based originated from the need to demonstrate the impacts of inadequate road riding quality on the SA economy in order to create awareness and illustrate the importance of proper and timely road maintenance and reconstruction. Although relevant information exists in this regard, the need existed specifically in South Africa during recent years to focus attention on this again, as spending on maintenance and rehabilitation of roads decreased significantly, specifically on rural networks $(21)$. The aim is to scientifically determine the potential effects that deteriorating riding quality can have on logistics cost and the broader economy of South Africa. The methodology includes identification of costs that can typically be attributed to deteriorating riding quality and analysis of the potential effects that worsening road conditions can have on each of the identified costs (based on actual data from a local LSP). The outcome of this analysis forms an important part of the annual SOL Survey for South Africa.

\section{Analysis planning and methodology}

The methodology followed in the project entailed the following steps:

- Identifying road sections in South Africa on which truck cost data and riding quality data are available;

- Obtaining the repair and maintenance costs of groups of trucks traveling on the selected road sections from the available truck database;

- Calculating the average cost per kilometer for each group of trucks on each selected road and comparing the results with the road roughness (in terms of International Roughness Index (IRI)) of each road section to determine the effect that riding quality have on vehicle operating cost, and

- Calculating savings in vehicle operating costs due to improved riding quality and comparison with the cost of road maintenance in order to determine the benefit-cost ratios of improved riding quality.

\section{Data}

Imperial Logistics, the leading LSP in southern Africa provided a database of actual maintenance costs of a fleet of 577 trucks over a period of 9 months, operating on a range of roads in South Africa. Typical trucks had Gross Vehicle Masses (GVM) of around $50000 \mathrm{~kg}$ and typically had 6 axles. Similar trucks were included in the database for the various routes, with the actual routes (and thus riding quality) being the main factor of difference in the analysis. The selected sample of trucks travelled for around 90 per cent of their active duty on dedicated routes, enabling their respective cost data to be attributed to the specific routes that they travelled on. The VOCs for the various trucks were also calculated from this database. Only these heavy trucks are included in the analysis, and all travel was on highways.

Table 1 contains a summary of the various road conditions, traffic volumes, operating costs and damage data for the study. The various routes from which the data were sourced are shown in Figure 3 . The following specific data are summarized:

- Actual road sections that the trucks traveled on and their respective riding quality over the period of operation (riding quality data obtained from the South African National Road Agency Limited (SANRAL));

- Actual truck repair and maintenance costs for vehicles on each of the routes (collected from actual company records), and

- Percentage of total vehicles with broken suspension and trailer components on each of the road sections (collected from actual company records).

Increasing economic activities in South Africa have resulted in growth in road transport and increases in vehicle populations on SA road networks. Road transport account for over 1400 million tones of total freight transported annually (11). Both the National Traffic and Information System (NATIS) and SANRAL traffic count data indicate that the rate of increases of trucks population in SA road networks is high, especially in the 6-axle and 7-axle category $(22,23)$. Trucks in the survey traveled between $10000 \mathrm{~km}$ and $1000000 \mathrm{~km}$.

The total distance traveled by each truck was calculated and used in order to calculate the average repair and maintenance costs per kilometer. The VOCs of the various trucks were calculated using current standard SA equations $(20,16)$ as well as the truck population information and riding quality information.

The additional costs of traveling with the suite of trucks on the 11 road sections indicated are compared to the typical maintenance and repair costs for these roads to obtain a benefit-cost ratio. The objective of this is to determine whether or not it is economically beneficial to keep the roads in a condition with a better riding quality. Obviously, improved riding quality will benefit all vehicle classes, however, the focus of this study is on the benefit affected to the specific truck types indicated.

\section{GENERAL OUTCOMES OF THE ANALYSES}

The data analysis provided the following major outputs:

- Relationship between riding quality and truck maintenance and repair costs; 
- Relationship between riding quality and vehicle operating costs, and

- Relationship between vehicle operating costs and road maintenance costs.

\section{Relationship between riding quality and truck maintenance and repair costs}

It was observed that costs associated with breakage of suspension and trailer components for trucks traveling on roads with poor riding quality made a significant contribution to the total truck repair and maintenance costs (Table 1). These problems are mostly caused by the vibration experienced by vehicles traveling on uneven roads. Apart from causing breakages of suspension and trailer components, excessive vehicle vibrations are translated to the transported cargo resulting in cargo damage.

The problem of vehicle vibration can be addressed from mechanical engineering side by designing a good vehicle suspension system with optimum vibration performance, or from pavement engineering through improved riding quality. The fact that breakages of suspension and trailer components are dominating indicates that the problem needs to be addressed from pavement engineering side through improved riding quality. The major need for a pavement engineering solution is driven by the fact that a direct relationship exists between the increased road roughness and increased truck repair and maintenance costs (Table 1 and Figure 4).

Comparing the observed truck repair and maintenance costs with road roughness, there is a significant increase in repair and maintenance costs as road roughness increases (Figure 4). The data in Figure 4 show the collected data from the study indicated, as well as data obtained from a recent US study ( 6 ) and converted to similar units than the South African study. The road roughness range for the US study was more limited than the South African study, but it is significant that similar cost ranges were observed for the lower range where data exist for both studies.

\section{Relationship between riding quality and vehicle operating costs}

The database of truck costs from the LSP were augmented with information on fuel, oil and tire costs to enable a relationship between total VOCs and riding quality to be performed. Analysis of the total VOCs against the riding quality of the various roads evaluated indicated an increasing trend (as would typically be expected). Full analysis of these costs is covered in a recent research project (20).

\section{Relationship between vehicle operating costs and road maintenance costs}

The first two steps of the analysis of VOCs against road riding quality supported the well-known trend that decreasing riding quality causes a direct increase in VOCs. A clear indication of the increasing damage to vehicle components was also demonstrated (Table 1 and Figure 4). An obvious recommendation from this data is that all roads should just be maintained to ensure as good as practical riding quality, to enable the lowest logistical cost component due to road roughness. However, this argument is not as simple, as the cost of maintaining roads to a desired riding quality should be added to the overall argument.

The road maintenance costs required to improve riding quality were thus compared to the saving in VOCs gained due to improvement of riding quality, and a benefit-cost ratio of such an improvement calculated. Firstly, the potential saving in VOCs for transporting goods on a good riding quality road was calculated. In order to simplify this computation of saving in VOCs, the following assumptions were made:

- Road maintenance will be conducted at an intervals of 7 years;

- Discount rate of 8 per cent was used;

- Exponential increase in road roughness after road maintenance (based on typical data sets for the type of roads investigated in South Africa (24)), and

- Constant volume of trucks on each road section.

Road maintenance costs were based on historical road maintenance projects for SANRAL. Although these costs depend on factors such as the geometry of the road, the materials involved and the specific pavement structure, the typical cost provides a good average for this range of roads with similar properties. These data showed typical road maintenance costs for similar roads and a similar period to be approximately ZAR 1 million per kilometer (US\$ 133 000) $(25,26)$.

The VOCs on roads ranging from very good to bad ranged between ZAR 3 and ZAR 7 per kilometer (US\$ 0.40 and US $\$ 0.93$ per kilometer) (focusing only on the truck types indicated earlier in this paper). A VOC of ZAR 3 per kilometer was thus taken as the VOC at year zero and the VOC was increased exponentially over a period of 7 years up to a maximum of ZAR 7 per kilometer (indicating the increased cost due to riding quality decrease over the same period). The maximum savings in VOC was thus ZAR 4 per kilometer. The present value of the savings calculated over a period of seven years was ZAR 8.92 per kilometer per truck (Table 2).

The total savings in VOCs were calculated by multiplying the average truck traffic volume on each road section during the analysis period by ZAR 8.92 (US\$ 1.19) per kilometer per vehicle. The benefit-cost ratio for each of the road sections was calculated using the average maintenance cost of ZAR 1 million 
(US\$ 133 000) per kilometer obtained from SANRAL. Table 3 indicates the average truck traffic volume, calculated VOC savings and benefit-cost ratios over the analysis period of 7 years on each of the road sections used for the study.

Comparing the anticipated road maintenance costs with savings in VOCs showed significant benefits due to improved riding quality with benefit-cost ratios between 7.2 and 12.8 for the selected road sections. Only the truck volume was used for the cost-benefit analyses and therefore the actual benefit-cost ratios should be higher than these figures. Although a different set of assumptions will probably lead to different ratios, these calculated ratios are viewed as significant indicators of the positive effect of road maintenance on vehicle damage costs.

\section{Linkages between road quality and logistics cost}

The results obtained from the comparison between road roughness and truck repair and maintenance cost indicate that repair and maintenance cost of a truck increase as the roughness of the road, on which the truck is traveling, increases. The increased truck repair and maintenance cost of a company, due to deteriorating road conditions will lead to an increase in the total logistics cost of that company.

Other costs that can potentially be attributed to deteriorating road quality are increased vehicle operating cost, increased fuel consumption, increased cargo damages and ultimately increased vehicle design and manufacturing costs. The analysis of the actual effects that road quality may have on these costs does not form part of this paper. However, an increase in any of these costs can potentially lead to an increase in the internal logistics cost of companies without adding any additional value to the final product. This will have negative effects on the total logistics cost of a country.

\section{Impact on the general economy, logistics and road maintenance}

The increase in internal logistics cost due to inadequate road conditions are experienced by most, if not all, transportation companies in a country. This figure eventually adds up to a significant increase in the logistics cost of a country. As the logistics cost of a country increases, the cost of its products in the global marketplace increases which can have devastating effects on the global competitiveness of that country (12). It is therefore of critical importance to manage logistics cost effectively and minimize unnecessary costs that can potentially be translated into higher product costs.

Results obtained from the analyses discussed in this paper indicate that the potential effect of deteriorating road quality on vehicle repair and maintenance costs, and ultimately the total logistics cost of a country, is significant. It is therefore imperative to create awareness of the potential impacts of bad roads amongst stakeholders to ensure that proper attention is given to the timely and proper maintenance of roads.

\section{CONCLUSIONS}

The objective of this paper is to present data to indicate that the effect of inadequate riding quality on VOCs and ultimately the logistic costs of a country can be substantial. This data should be utilized to motivate for the adequate funding of road maintenance in the country, as the beneficial effect of these maintenance actions stretches much wider than the condition of road infrastructure. Based on the information provided in this paper the following conclusions are drawn:

- Inadequate riding quality causes significant increases in vehicle operating costs manifesting as increased breakages of specifically suspension and trailer components;

- Improvement in riding quality is the most direct method of decreasing these VOCs as the root cause of the problem is solved;

- Benefit-cost analysis comparing the potential savings in VOC while transporting goods on roads with improved riding quality with the maintenance costs of roads, indicate a major benefit in maintaining roads with good riding quality in a country

\section{RECOMMENDATIONS}

Based on the analyses contained in this paper it is recommended that the limited study that this paper was based on be extended to incorporate a range of different routes and vehicle types, to ultimately express the cost of inadequate riding quality as a percentage of the GDP of the country.

\section{ACKNOWLEDGEMENTS}

The generous financial and practical support of Imperial Logistics for the State of the Logistics survey, and the permission of the Executive Director of CSIR Built Environment to publish these results are acknowledged. Discussions with Prof Carl Monismith on the original concept are also gratefully acknowledged. 


\section{REFERENCES}

1. ANON, The First State of the Logistics survey for South Africa - The case for measurement and revitalisation of basic logistics infrastructure in our dual economy. CSIR BE, Pretoria, South Africa, 2004.

2. ANON, Second Annual State of the Logistics Survey for South Africa - Defining research priorities for Developmental logistics. CSIR BE, Pretoria, South Africa, 2005.

3. STEYN, W. J. v. d. M., W. L. BEAN, and C. L. MONISMITH. The potential costs of bad roads in South Africa, $5^{\text {th }}$ Annual State of Logistics survey for South Africa. CSIR, Pretoria, South Africa, 2008.

4. Pavement Management Systems, Organisation for Economic Cooperation and Development, Paris, France, 1987

5. NCHRP Synthesis 330. Public benefits of highway system preservation and maintenance. A synthesis of highway practice. TRB, Washington, D.C. 2004.

6. ZAABAR, I. and CHATTI, K., Identification of Localized Roughness Features and Their Impact on Vehicle Durability. $11^{\text {th }}$ International Symposium on Heavy Vehicle Transportation Technology (HVTT11), 14-17 March, 2010, Melbourne, Australia.

7. STEYN, W.J.vdM. Considerations of vehicle-pavement interaction for pavement design. PHD Thesis, University of Pretoria, South Africa. 2001.

8. GILLESPIE, T.D. Fundamentals of vehicle dynamics. Warrendale, PA: Society of Automotive Engineers. 1992.

9. AHLIN K. and GRANLUND J.N.O. Relating Road Roughness and Vehicle Speed to Human Whole Body Vibration and Exposure Limits. The International Journal of Pavement Engineering, 2002, Vol. 3(4) pp. 207-216. 2002.

10. FHWA. Roughness Trends of Flexible Pavements. Investigation of Development of Pavement Roughness. Technical Report FHWA-RD-97-147, Washington. 1997.

11. HAVENGA, J. H., DE JAGER, N., VAN EEDEN, J., JACOBS, N. and BRAUN, M. The state of logistics in South Africa - exposure to external risks, $5^{\text {th }}$ Annual State of Logistics survey for South Africa. CSIR, Pretoria, South Africa, 2008.

12. $\quad 6^{\text {th }}$ Annual State of Logistics survey for South Africa. CSIR. Pretoria. South Africa. 2009.

13. JORGENSEN, A.A. Transport cost externalities: A discussion paper. $28^{\text {th }}$ Annual South African Transport Conference, Pretoria, South Africa, 6 to 9 July 2009.

14. WATANATADA, T. DHARESHWAR, A.M. and REZENDER LIMA, P.R.S. Vehicle Speed and Operating Costs: Model for planning and Management. Johns Hopkins University Press. Baltimore. 1987.

15. CROSSLEY, C. P. Rural Road Characteristics and Vehicle Operating Costs in Developing Countries, Journal Of Terramechanics, Vol. 18, No. 4, pp. 209-228. 1982.

16. DU PLESSIS, H.W. and SCHUTTE, I.C. Road roughness effects on vehicle operating costs: Southern Africa relations for use in economic analyses and in road management systems. RDAC project report PR 88/070/3. Division of Roads and Transport Technology, CSIR, Pretoria.1991.

17. THOMPSON, R.J. and VISSER, A.T. Mine haul road maintenance management systems. The Journal of the South African institute of Mining and Metallurgy. SA ISSN OO35-223X/3. 2003.

18. CHESHER, A. and HARRISON, R. Vehicle speeds and operating costs: Evidence from Developing countries. World Bank Publication, Johns Hopkins University Press. 1987.

19. BENNET, C.R. and GREENWOOD, I.D. HDM-4 Highway Development and Management, Volume Seven. Modelling Road Users and Environmental Effects in HDM-4, PIARC, Paris. 2001.

20. KOMBA, J. Analysis of effect of road conditions on vehicle operating costs. B.Eng dissertation, University of Pretoria, Pretoria, South Africa. 2009.

21. NDEBELE, S. Keynote address at the Road Construction and Maintenance Summit, Midrand, Johannesburg, South Africa, 24 May 2010.

22. eNaTIS. Live vehicle population as per National Traffic Information System. Downloadable from eNaTIS web site: http://www.fleetwatch.co.za/. Accessed on 12 May 2010.

23. SANRAL. Sanral traffic count year book 2003. Pretoria.

24. ANON. The damaging effects of overloaded heavy vehicles on roads. PAD27 (Fourth Edition), Department of Transport, Pretoria, South Africa. April 1997.

25. SANRAL. Annual Report 2008. The Southern African National Road Agency. Downloadable from SANRAL website: http://www.nra.co.za. Accessed on 12 June 2010.

26. SANRAL. Value of Asset Preservation: Data Collection. Downloadable from SANRAL website: http://www.nra.co.za. Accessed on 12 June 2010. 
TABLE 1 Summary of Road Sections, Riding Qualities and Costs Used in the Analysis

\begin{tabular}{|c|c|c|c|c|}
\hline $\begin{array}{l}\text { Section } \\
\text { Number }\end{array}$ & $\begin{array}{c}\text { Location } \\
\text { Origin and destination } \\
\text { (route number) } \\
\text { [Road length, ADTT*] }\end{array}$ & $\begin{array}{c}\text { Average } \\
\text { Road } \\
\text { Roughness } \\
\text { (IRI) } \\
{[\mathbf{m} / \mathbf{k m}]} \\
\end{array}$ & $\begin{array}{c}\text { Average Repair } \\
\text { and Maintenance } \\
\text { cost } \\
{[\mathrm{ZAR} / \mathbf{k m}]}\end{array}$ & $\begin{array}{l}\text { Percentage vehicles with } \\
\text { broken suspension / } \\
\text { trailer components [\%] }\end{array}$ \\
\hline 1 & $\begin{array}{c}\text { Gauteng to Durban (N3) } \\
{[630 \mathrm{~km}, 3000]}\end{array}$ & 2.7 & 0.90 & 5 \\
\hline 2 & $\begin{array}{c}\text { Gauteng to Nelspruit (N4) } \\
{[355 \mathrm{~km}, 1400]}\end{array}$ & 2.9 & 0.82 & 0 \\
\hline 3 & $\begin{array}{l}\text { Gauteng network } \\
\text { [Road length vary] }\end{array}$ & 3.2 & 0.84 & 3 \\
\hline 4 & $\begin{array}{c}\text { Gauteng to Witbank } \\
\text { (N12) }[140 \mathrm{~km}, 2000]\end{array}$ & 3.4 & 1.27 & 2 \\
\hline 5 & $\begin{array}{l}\text { Gauteng to Rustenburg } \\
\text { (N4) }[140 \mathrm{~km}, 500]\end{array}$ & 3.3 & 1.04 & 4 \\
\hline 6 & $\begin{array}{l}\text { Gauteng to Richardsbay } \\
\text { (N17 and N2) } \\
{[600 \mathrm{~km}, 900]}\end{array}$ & 3.6 & 1.31 & 4 \\
\hline 7 & $\begin{array}{c}\text { Johannesburg to } \\
\text { Vereeniging (R82) } \\
{[70 \mathrm{~km}, 900]} \\
\end{array}$ & 3.6 & 1.57 & 6 \\
\hline 8 & $\begin{array}{c}\text { Gauteng to Cape Town } \\
\text { (N12 and N1) } \\
{[1400 \mathrm{~km}, 2000]} \\
\end{array}$ & 3.6 & 1.29 & 2 \\
\hline 9 & $\begin{array}{c}\text { Gauteng to Botswana } \\
\text { (N4) [280 km, 500] }\end{array}$ & 3.9 & 1.35 & 10 \\
\hline 10 & $\begin{array}{l}\text { Newcastle to Gauteng } \\
\text { (N11 and N17) } \\
{[290 \mathrm{~km}, 700]}\end{array}$ & 4.2 & 2.09 & 59 \\
\hline 11 & $\begin{array}{l}\text { Gauteng to Construction } \\
\text { sites [Road length vary] }\end{array}$ & 4.3 & 2.13 & 5 \\
\hline & Median & 3.6 & 1.29 & Not applicable \\
\hline \multicolumn{2}{|r|}{ Standard deviation } & 0.48 & 0.45 & Not applicable \\
\hline
\end{tabular}

*ADTT - Average Daily Truck Traffic 2008 
TABLE 2 Potential Saving in Vehicle Operating Costs (for the trucks evaluated in this paper, excluding other vehicle types)

\begin{tabular}{|c|c|}
\hline Year & Potential Savings [ZAR/km (US\$/km)] \\
\hline 0 & $0.00(0.00)$ \\
\hline 1 & $0.50(0.07)$ \\
\hline 2 & $0.80(0.11)$ \\
\hline 3 & $1.10(0.15)$ \\
\hline 4 & $1.60(0.21)$ \\
\hline 5 & $2.20(0.29)$ \\
\hline 6 & $3.00(0.40)$ \\
\hline 7 & $4.00(0.53)$ \\
\hline $\begin{array}{c}\text { Nett Present Value [ZAR / km / vehicle } \\
\text { (US\$ / km / vehicle)] }\end{array}$ & $\mathbf{8 . 9 2 ( 1 . 1 9 )}$ \\
\hline
\end{tabular}

TABLE 3 Anticipated Traffic Volume, VOC Savings and Benefit-Cost Ratios on Selected Road Sections

\begin{tabular}{|c|c|c|c|c|}
\hline $\begin{array}{l}\text { Section } \\
\text { Number }\end{array}$ & Location & $\begin{array}{c}\text { Average annual } \\
\text { truck traffic } \\
\text { volume } \\
\end{array}$ & $\begin{array}{c}\text { Potential VOC } \\
\text { Savings } \\
{[\mathrm{ZAR} / \mathbf{k m}(\mathrm{US} \$ \mathbf{k m})]} \\
\end{array}$ & Benefit-Cost Ratio \\
\hline 1 & Gauteng to Durban (N3) & 204400 & $\begin{array}{r}12762522 \\
(1701670)\end{array}$ & 12.8 \\
\hline 2 & $\begin{array}{l}\text { Gauteng to Nelspruit } \\
\text { (N4) }\end{array}$ & 127750 & $\begin{array}{r}7976577 \\
(1063544)\end{array}$ & 8.0 \\
\hline 3 & Gauteng network & \multicolumn{3}{|c|}{ 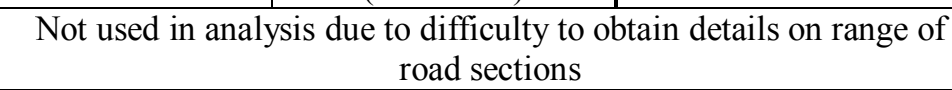 } \\
\hline 4 & $\begin{array}{l}\text { Gauteng to Witbank } \\
\text { (N12) }\end{array}$ & 116800 & 7292870 (972 383) & 7.3 \\
\hline 5 & $\begin{array}{l}\text { Gauteng to Rustenburg } \\
\text { (N4) }\end{array}$ & 109500 & $6837066(911609)$ & 6.8 \\
\hline 6 & $\begin{array}{c}\text { Gauteng to Richardsbay } \\
\text { (N17 and N2) }\end{array}$ & 158775 & $\begin{array}{c}9913745 \\
(1321833)\end{array}$ & 9.9 \\
\hline 7 & $\begin{array}{c}\text { Johannesburg to } \\
\text { Vereeniging (R82) }\end{array}$ & 157680 & 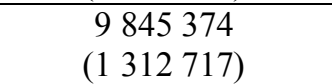 & 9.8 \\
\hline 8 & $\begin{array}{l}\text { Gauteng to Cape Town } \\
\text { (N12 and N1) }\end{array}$ & 140160 & $\begin{array}{c}8751444 \\
(1 \quad 166859)\end{array}$ & 8.8 \\
\hline 9 & $\begin{array}{l}\text { Gauteng to Botswana } \\
\text { (N4) }\end{array}$ & 116070 & $7247290(966305)$ & 7.2 \\
\hline 10 & $\begin{array}{l}\text { Newcastle to Gauteng } \\
\text { (N11 and N17) }\end{array}$ & 135780 & 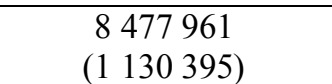 & 8.5 \\
\hline 11 & $\begin{array}{c}\text { Gauteng to Construction } \\
\text { sites }\end{array}$ & \multicolumn{3}{|c|}{$\begin{array}{c}\text { Not used in analysis due to difficulty to obtain details on range of } \\
\text { road sections }\end{array}$} \\
\hline
\end{tabular}




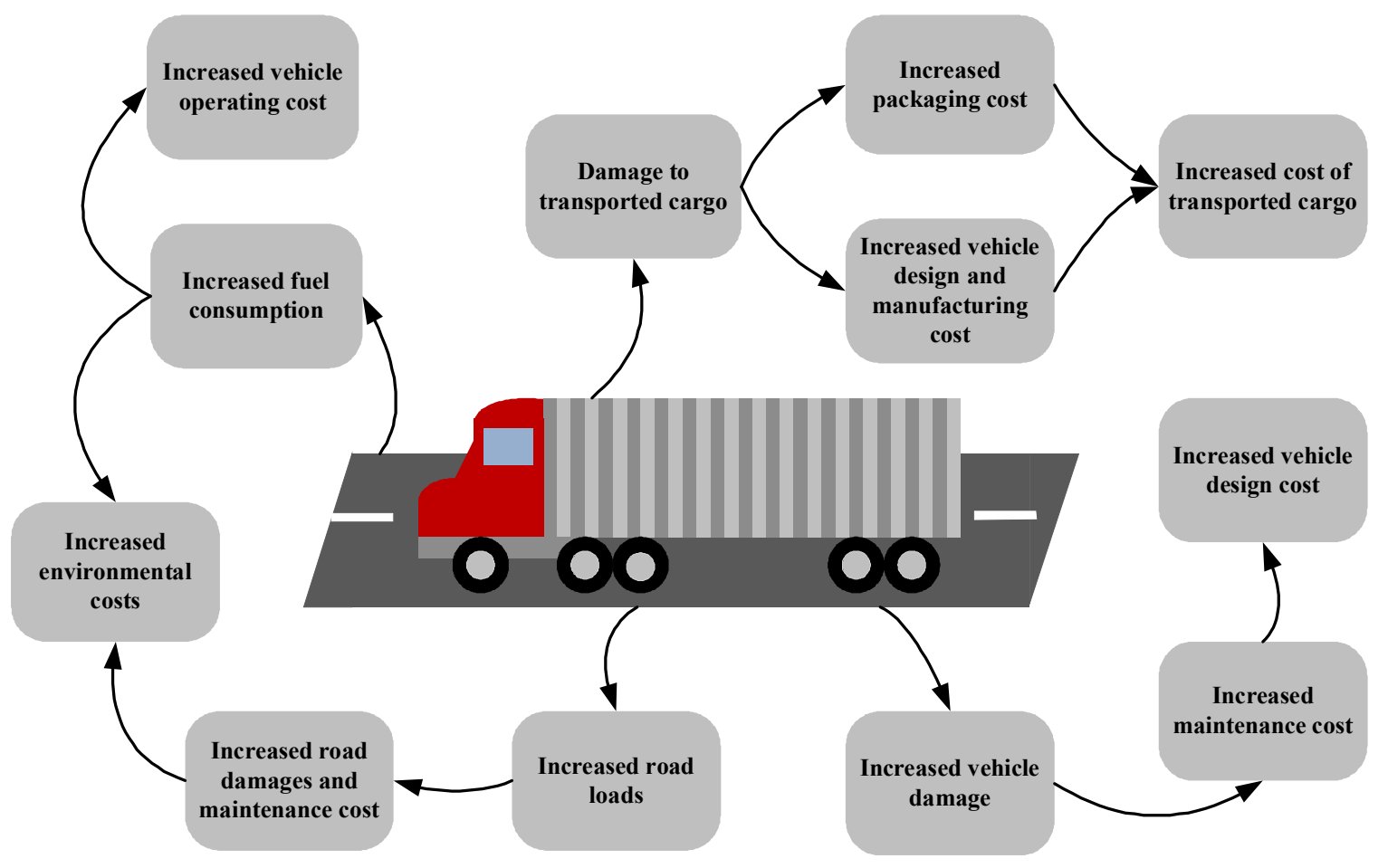

FIGURE 1 Conceptual indication of the effect of riding quality on truck logistics costs (3).

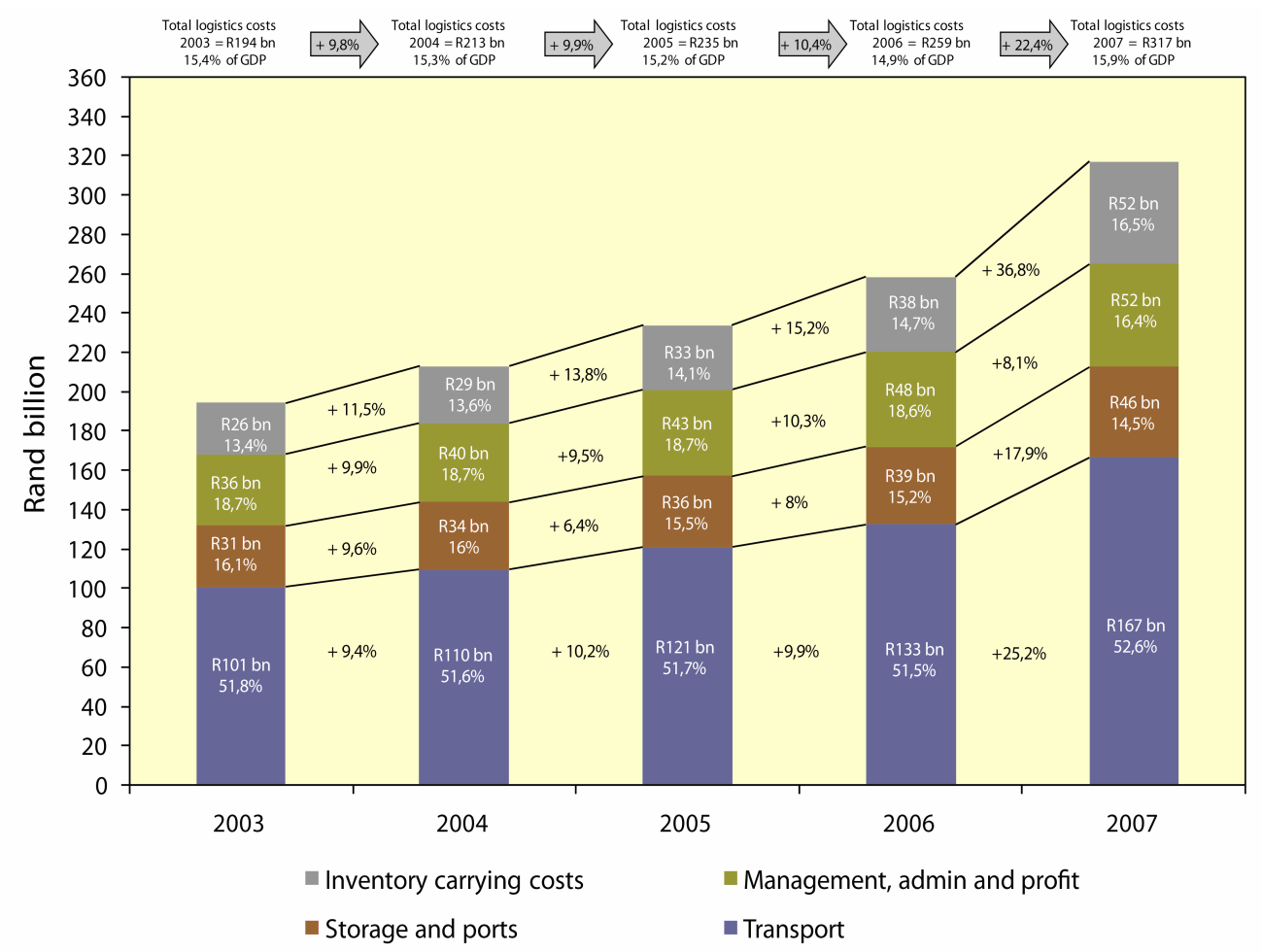

FIGURE 2 Costs of logistics in South Africa (11). 


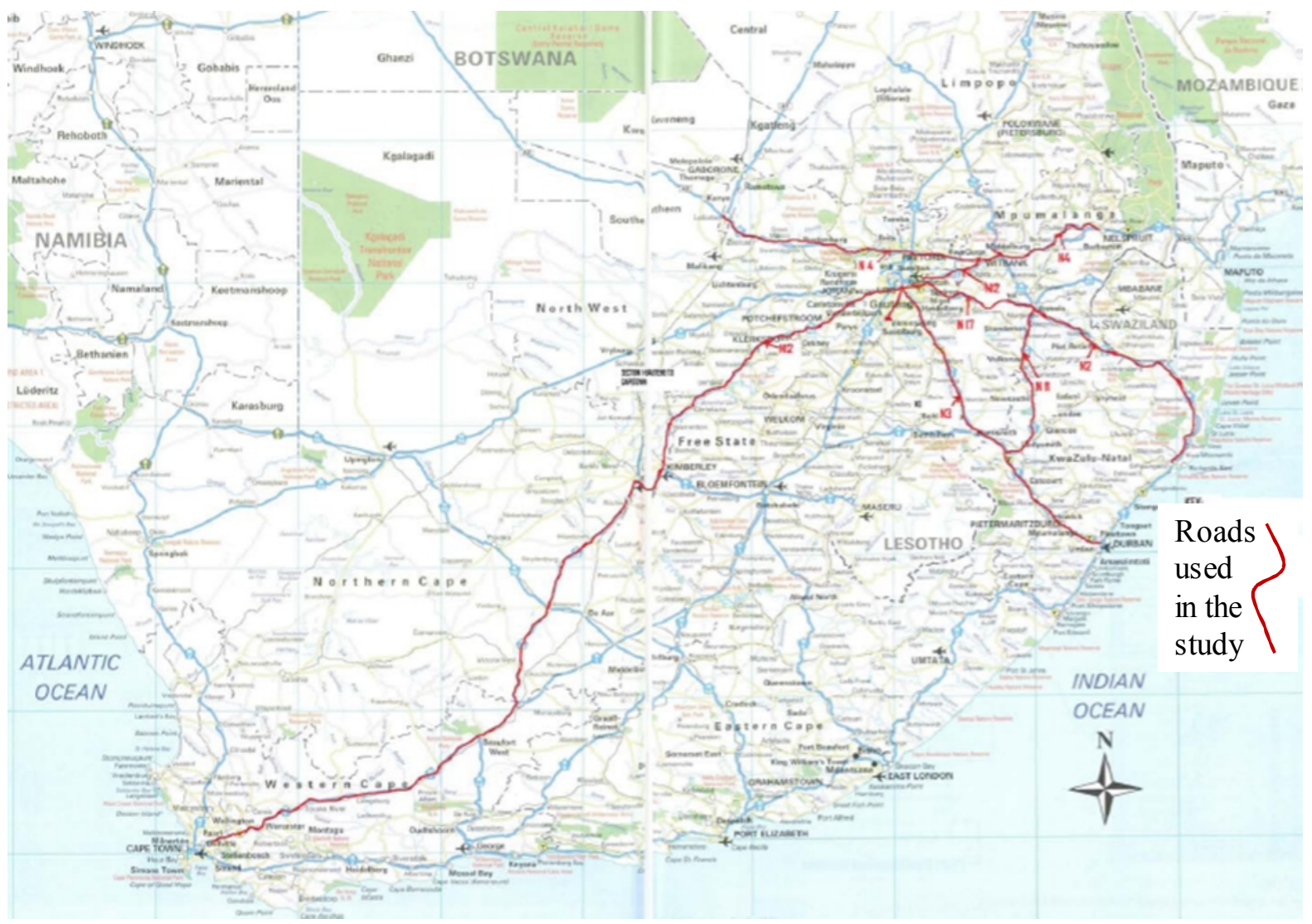

FIGURE 3 Routes from which data for this paper were sourced.

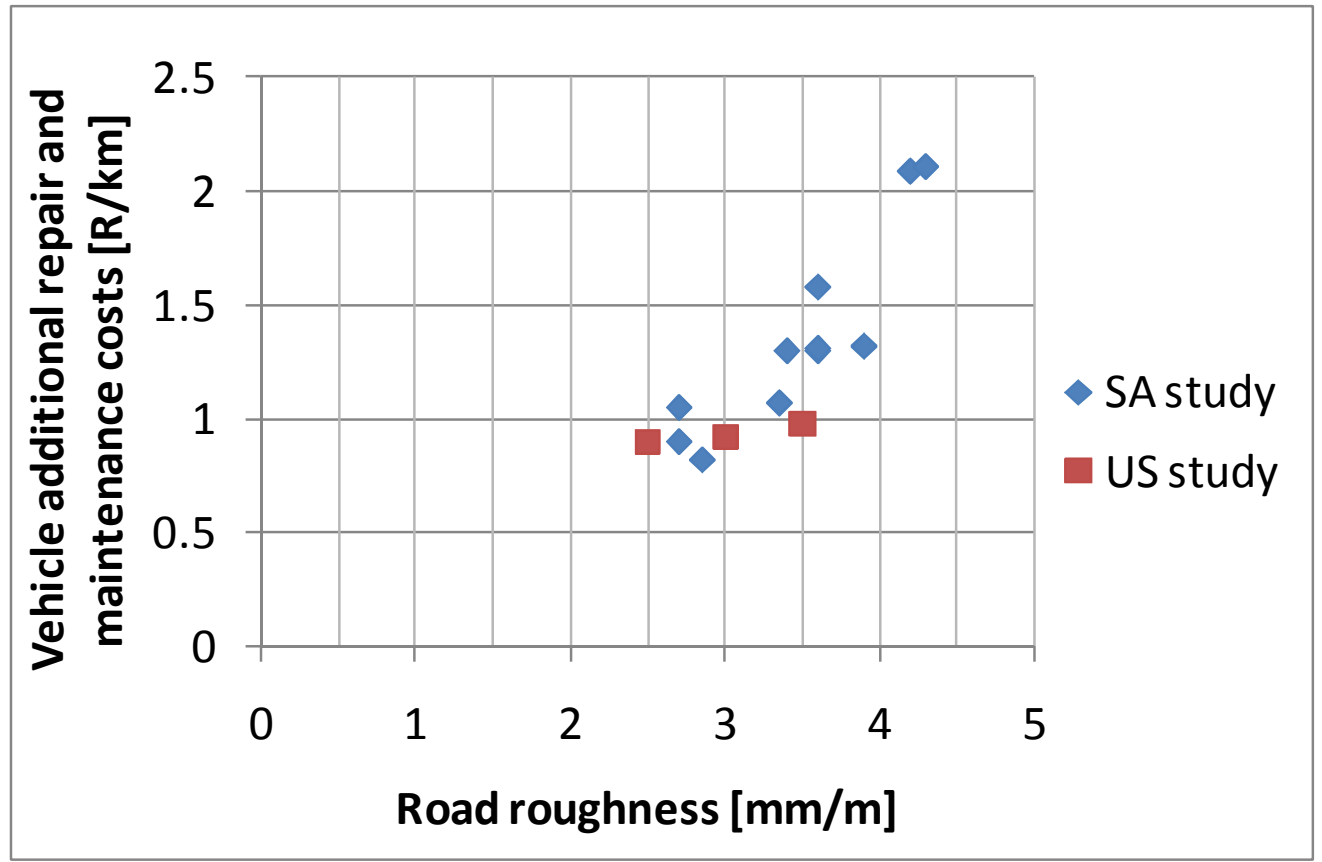

FIGURE 4 Road roughness versus Actual truck repair and Maintenance cost for current study and a recent US study (6). 